\title{
Hyoscyamus labiatus sp. nov. (Solanaceae: Hyoscyameae) from Henan, China: implications for the delimitation of Hyoscyamus
}

Yan-Yan Liu

Henan Agricultural University

Qi-Rui Wang

Chinese Academy of Forestry

Zeng-Lu Mi

Henan Agricultural University

Jia-Mei Li ( $\square$ jiamei_li@126.com )

Henan Agricultural University

Original Article

Keywords: Archihyoscyamus, Hyoscyameae, phylogeny, Solanaceae, taxonomy

Posted Date: November 1st, 2021

DOI: https://doi.org/10.21203/rs.3.rs-1010205/v1

License: (c) (i) This work is licensed under a Creative Commons Attribution 4.0 International License.

Read Full License 


\section{Abstract \\ Background}

Hyoscyamus, the largest genus in the tribe Hyoscyameae, harbors more than 20 species. Although the monophyly of Hyoscyamus is supported by both morphological and molecular phylogenetic studies, the delimitation of Hyoscyamus has been hotly debated in different classifications. Here, we report a new species of Hyoscyamus (Solanaceae) from Henan Province, China, and discuss the delimitation of Hyoscyamus.

\section{Results}

This species is morphologically similar to the known species of Hyoscyamus and its close related genus Archihyoscyamus, but can be distinguished by corolla 2-lipped, adaxial lip 3-lobed and much longer than abaxial lips, tube slender at base, and stamens 5 , inserted on inner side of disk, free, obviously unequal, and exceeding corolla. Phylogenetic analysis based on four chloroplast markers including $r b c L, n d h F$, trnC-psbM and trnL-trnF, strongly suggested that the new species was sister to a monophyletic group containing all species of Hyoscyamus and Archihyoscyamus previously described.

\section{Conclusions}

Both the morphological observations and molecular phylogenetic analyses support the recognition of Hyoscyamus labiatus as a new species. Our study also showed that Archihyoscyamus should be a synonym of Hyoscyamus. The delimitation of Hyoscyamus is thus revised in our study.

\section{Background}

Solanaceae has approximately 21 tribes, 100 genera and 2,500 species (Olmstead et al. 1999; Hunziker 2001; Olmstead et al. 2008), including several economically important crops and ornamentals. Within this family, the tribe Hyoscyameae, containing more than 40 species, was strongly supported to be monophyletic (Olmstead et al. 2008; Tu et al. 2010; Sanchez-Puerta and Abbona 2014). It was also the only group mainly distributed in Eurasia and centered on both the Hengduan Mountains and Mediterranean-Turanian region (Tu et al. 2010). According to previous studies, seven genera, c. Anisodus Link et Otto, Atropa L., Atropanthe Pascher, Hyoscyamus L., Physochlaina G. Don, Przewalskia Maxim., and Scopolia Jacq. were widely accepted in this group (Lu and Zhang 1986; D'Arcy and Zhang 1992; Olmstead et al. 2008). All the Hyoscyameae taxa are characterized by circumscissile capsular fruits except Atropa, which possess a berry fruit (Knapp 2002) and with a basal-most phylogenetic position in the molecular phylogenetic analyses (Olmstead et al. 1999; Yuan et al. 2006; Tu et al. 2010; SanchezPuerta and Abbona 2014; Ghahremaninejad and Riahi 2021; Lei et al. 2021). 
Hyoscyamus, the largest genus in the tribe Hyoscyameae, harbors more than 20 species (Yousaf et al. 2008; Satil et al. 2015). Although the monophyly of Hyoscyamus is supported by both morphological (usually sessile solitary flowers and spiny tips of fruit calyces) (Tu et al. 2010) and molecular phylogenetic studies (Hajrasouliha et al. 2014; Ghahremaninejad and Riahi 2021). However, the delimitation and infrageneric classification of Hyoscyamus has been hotly debated in previous studies. In Flora Iranica, 23 species have been reported in Hyoscyamus, which divided into two subgenera (Subg. Dendrotericon and Subg. Hyoscyamus) and four sections (Sect. Hyoscyamus, Sect. Pumilio, Sect. Euhyoscyamus, and Sect. Chamaehyoscyamus) (Schönbeck-Temesy 1972). However, the recognized subgenera and sections did not form monophyletic groups in the phylogenetic analysis (Hajrasouliha et al. 2014; Ghahremaninejad and Riahi 2021). Khatamsaz (1998) treated some species of Hyoscyamus in Iran as synoyms, and introduced a new species, leaving a total of 13 species in Hyoscyamus only. Otherwise, a monotypic genus Archihyoscyamus A.M. Lu was described based on one species transferred from Hyoscyamus (H. leptocalyx Stapf) (Lu 1997).

Six genera of Hyoscyameae with approximately 16 species and three varieties were found in China, including Anisodus Link et Otto (four species, three varieties), Atropanthe Pascher (one species), Hyoscyamus L. (three species), Physochlaina G. Don (seven species) and Przewalskia Maxim (one species) (Zhang et al. 1994; Tu et al. 2010). Only two species of the tribe, Physochlaina infundibuluris Kuang and Hyoscyamus niger L., occur in Henan Province, China. In 2017, during a survey of forest germplasm resources in Henan Province, China, we encountered an unfamiliar taxon, which shares similar vegetative attributes and occurs in similar habitats with Triaenophora rupestris (Hemsl.) Soler in Scrophulariaceae Juss. In 2020 and 2021, we collected its flowers and found that this taxon was morphologically similar to the species of Hyoscyamus.

To clarify the systematic position of the new taxon, four widely used plastid markers are sequenced and the phylogeny of Hyoscyameae is reconstructed. Based on all these evidence, a new species, Hyoscyamus labiatus, is described here, and also the delimitation of Hyoscyamus is discussed.

\section{Methods}

\section{Morphological analyses}

Morphological observations and measurements of the new species were carried out, based on the study of living plants and herbarium specimens. Measurements of flowers and rhizomes were taken from living plants. Photographs of Hyoscyamus labiatus were taken in the field and are showed in Fig. 1. The voucher specimens of the new species were deposited in Henan Agricultural University Herbarium (HEAC).

\section{Dna Extraction, Amplication And Sequencing Of Four Plastid Loci}


Specimens and silica-dried leaf material of Hyoscyamus labiatus were collected from the only known population. Total genomic DNA was extracted from silica gel-dried leaves with CTAB method. To infer the systematic position of the new species in the tribe Hyoscyameae, four plastid markers, including $n d h F$, $r b c L$, $t r n L-F$ and $t r n C-p s b M$, were amplified and sequenced. Primers for these four genes followed Olmstead and Sweere (1994), Dong et al. (2014), Taberlet et al. (1991), and Tu et al. (2008), respectively (Table S1). PCR amplification was conducted with a reaction volume of $25 \mathrm{uL}$ containing 10-50 $\mathrm{ng}$ of DNA template, $1 \times$ Ex Buffer (Mg2+ plus), 200 umol/L of each dNTP, 6.25 pmol of each primer pair, and $0.75 \mathrm{U}$ of Taq DNA polymerase (TakaRa Biotech Co., Dalian, China). PCR cycles were as follows: 3 min at $94{ }^{\circ} \mathrm{C}, 36$ cycles of $30 \mathrm{~s}$ at $94{ }^{\circ} \mathrm{C}, 30 \mathrm{~s}$ at $50-58{ }^{\circ} \mathrm{C}$, and $1-5 \mathrm{~min}$ at $72^{\circ} \mathrm{C}$, with a final elongation for 10 min at $72{ }^{\circ} \mathrm{C}$. The PCR products were directly sequenced with an ABI Prism 3730xI sequencer (PE Applied Biosystems). The sequences reported in this study were deposited in GenBank (https://www.ncbi.nlm.nih.gov/) under accession numbers MT997072- MT997075. The same four plastid gene sequences of other taxa in the tribe Hyoscyameae were retrieved from GenBank and the accession number are given in Table S2.

\section{Phylogenetic Analysis (Dup: Abstract ?)}

The sequences of single plastid loci were firstly aligned using Clustal X (Thompson et al. 1997) and further manually adjusted with BioEdit v7.2.5 (Hall 1999). Phylogenetic trees were reconstructed individually for each plastid loci and the combined gene dataset. Maximum likelihood (ML) analyses were performed under the GTRGAMMA model by RaxML v8.1.17 (Stamatakis 2014) with 100 bootstrap replicates. Lycium chinense and Solanum lycopersicum were chosen as outgroups.

\section{Results}

\section{Taxonomy}

Hyoscyamus L.Sp. Pl. 1: 179. 1753. - Type: Hyoscyamus nigerL.

Archihyoscyamus A.M. Lu, Adansonia 19(1): 135-138. 1997. -Type: Hyoscyamus leptocalyx Stapf.

Herbs annual, biennial, or perennial, erect or sprawling; pubescence of simple glandular hairs. Leaves solitary, paired but not opposite or in whorls, sometimes forming a rosette; leaf blade sinuate, coarsely dentate or pinnately lobed or parted, rarely entire, apex acute. Inflorescences of solitary axillary flowers, sometimes condensed into scorpioid racemes or spikes. Calyx tubular-campanulate, urceolate, or obconical, becoming enlarged, lobes erect or spreading, needlelike or obtuse-rounded. Corolla actinomorphic or zygomorphic, campanulate or funnelform. Stamens inserted in corolla tube, usually slightly exserted; anthers dehiscing longitudinally. Disc sometimes indistinct. Ovary 2-locular; ovules numerous. Fruiting calyx unequal or equal, completely or incompletely enveloping and longer than capsule, lobes with strong or unobvious marginal veins produced into mucros. Capsules dehiscent by an operculum slightly distal to middle. Seeds reniform or discoid, minutely pitted; embryo ringlike or coiled. 
Hyoscyamus labiatus Y.Y. Liu, Q.R. Wang \& J.M. Li, sp.nov. (畈因) (Figs.1 and 2)

Type: China, Henan Province: Yellow River Grand Canyon, Mianchi County, Sanmenxia City, alt. 258.4 m, $111^{\circ} 40.5^{\prime}$ E, 3456.64' N, 22 May, 2020, Li Jiamei et Wang Qirui 20205221 (holotype, HEAC!). ibid. 14 July, 2017, Li Jiamei et Liu Yao 20177141; 14 April, 2021, Li Jiamei, Wang Qirui et Wang Fuqian 20214141, (Paratype: HEAC!).

\section{Diagnosis}

Hyoscyamus labiatus is similar to H. leptocalyx by the capsules dehiscent around slightly distal, with apical "lid" deciduous and basal portion persistent, pedicels much longer than leaves, but differs in having corolla 2-lipped, adaxial lips 3-lobed and much longer than abaxial lips, tube slender at base, and stamens 5 , inserted on inner side of disk, free, obviously unequal, and exceeding petals (Table 1 ).

Table 1

The morphological comparison between Hyoscyamus labiatus and other similar species in Hyoscyamus

\begin{tabular}{|c|c|c|c|c|}
\hline Characters & H. labiatus & H. leptocalyx & H. senecionis & H. aureus \\
\hline Stem & $\begin{array}{l}30-50 \mathrm{~cm} \text {, dense non- } \\
\text { glandular and glandular } \\
\text { hairs. }\end{array}$ & $\begin{array}{l}10-15 \mathrm{~cm}, \\
\text { pubescent. }\end{array}$ & $30-70 \mathrm{~cm}$, pubescent. & $\begin{array}{l}30-70 \mathrm{~cm} \text {, non- } \\
\text { glandular and } \\
\text { glandular } \\
\text { hairs. }\end{array}$ \\
\hline Leave & $\begin{array}{l}\text { alternate, often paired but } \\
\text { not opposite or in whorls; } \\
\text { leaf blade } 3-5 \times 3.5-5.5 \mathrm{~cm}\end{array}$ & $\begin{array}{l}\text { alternate; leaf } \\
\text { blade } 1-2 \times 1.5- \\
2.7 \mathrm{~cm}\end{array}$ & $\begin{array}{l}\text { alternate, often } \\
\text { paired but not } \\
\text { opposite; leaf blade } \\
2-4 \times 3-5 \mathrm{~cm}\end{array}$ & $\begin{array}{l}\text { alternate, leaf } \\
\text { blade 3-5×3- } \\
5 \mathrm{~cm}\end{array}$ \\
\hline Pedicel & 5- $6.5 \mathrm{~cm}$ long & to $2.8 \mathrm{~cm}$ long & to $3 \mathrm{~cm}$ long & to $1.5 \mathrm{~cm}$ long \\
\hline Calyx & $\begin{array}{l}\text { lobes unequal, } 5 \mathrm{~mm} \text { long, } \\
\text { apex obtuse-rounded }\end{array}$ & $\begin{array}{l}\text { lobes equal, } \\
2 \mathrm{~mm} \text { long, } \\
\text { apex obtuse- } \\
\text { rounded, }\end{array}$ & $\begin{array}{l}\text { lobes unequal, } 5 \mathrm{~mm} \\
\text { long, apex acute }\end{array}$ & $\begin{array}{l}\text { lobes equal, } \\
5 \mathrm{~mm} \text { long, } \\
\text { apex acute }\end{array}$ \\
\hline Corolla & Zygomorphic & Actinomorphic & Zygomorphic & Zygomorphic \\
\hline Tube & $\begin{array}{l}\text { ca. } 1.2 \mathrm{~cm} \text { long, ca. } 1.2 \mathrm{~cm} \\
\text { wide }\end{array}$ & $\begin{array}{l}\text { ca. } 0.2 \mathrm{~cm} \\
\text { long, ca. } 0.6 \mathrm{~cm} \\
\text { wide }\end{array}$ & $\begin{array}{l}\text { ca. } 1 \mathrm{~cm} \text { long, ca. } 0.8 \\
\text { cm wide }\end{array}$ & $\begin{array}{l}\text { ca. } 1.3 \mathrm{~cm} \\
\text { long, ca. } 0.8 \\
\text { cm wide }\end{array}$ \\
\hline Stamens & $\begin{array}{l}\text { unequal, filament } 1.5- \\
2.5 \mathrm{~cm} \text { long }\end{array}$ & $\begin{array}{l}\text { equal, filament } \\
1 \mathrm{~cm} \text { long }\end{array}$ & $\begin{array}{l}\text { equal, filament } \\
1.5 \mathrm{~cm} \text { long }\end{array}$ & $\begin{array}{l}\text { equal, } \\
\text { filament } \\
1.1 \mathrm{~cm} \text { long }\end{array}$ \\
\hline
\end{tabular}

Description: Perennial herbs, 30-50 cm tall; Stems 30-45 cm long, apparently from a deep and stout rhizome which is not collected in the stone seam, at first spreading but later erect, bases somewhat woody with age, well-branched below. Stems, leaves, petiole, pedicel and calyx dense non-glandular and glandular hairs, long and short hairs intermixed in varying proportions; Leaves alternate, sometimes paired but not opposite or in whorls; petiole 1.5-4 cm long, the longer petioles below and the shorter ones 
above; leaf blade broadly ovate, deltoid subreniform, $3-5 \mathrm{~cm}$ long, $3.5-5.5 \mathrm{~cm}$ wide, with teeth generally 3-4 deltoid per side; leaf bases unequal, cordate, rounded, or truncate. Flowers solitary, axillary; pedicel $5-6.5 \mathrm{~cm}$ long, pubescent. Calyx $1 \mathrm{~cm}$ long, 5 -lobed to halfway, ovate, apex obtuse-rounded. Corolla double longer than the calyx, up to $2.5 \mathrm{~cm}$ long, greenish yellow, with dark green reticulations. Corolla 1.5-1.8 cm in diam; tube ca. $1.2 \mathrm{~cm}$ long, ca. $1.2 \mathrm{~cm}$ wide in throat. Stamens 5, inserted at the corolla base, exserted, $1.5-2.5 \mathrm{~cm}$ long, arranged in three levels: one long, two middle, and two shorter; tube slender at base, exserted, dilated to throat; upper lip 3-lobed, lower lip entire. Filament glabrescent, inserted at the corolla base. Anther 2-6 mm long. Ovary ovoid, 2-locular with many ovules, style glabrescent, $2 \mathrm{~cm}$ long; stigma capitate. Fruiting calyx subrotate, $8-10 \mathrm{~mm}$ in diam., the lobes reflexed, 5 $\mathrm{mm}$ long, $3 \mathrm{~mm}$ wide. Fruiting pedicels elongating, to $15-18 \mathrm{~cm}$ long, densely pubescent. Capsule oval elliptic, $6 \mathrm{~mm}$ in diam in widest part. Seeds subovoid-oblong to irregularly rectangular, yellow red, $1.2 \mathrm{~mm}$ long, $1 \mathrm{~mm}$ wide, densely papillate.

\section{Etymology}

The specific epithet indicates the corolla 2-lipped, which is the most obvious unique character of the new species in the tribe.

Distribution, habitat and conservation status: Currently, Hyoscyamus labiatus is known only from Yellow River Grand Canyon in Mianchi County, Henan, China. The type population consisted of only about 1000 individuals in nearly inaccessible sites on the high limestone cliffs. A preliminary assessment of the risk of extinction was conducted according to the International Union for Conservation of Nature (IUCN) Red List Categories and Criteria (https://www.iucn.org/), we thereby consider that $H$. labiatus should be classified as near threatened (NT).

\section{Phylogenetic Analysis}

The four plastid loci ( $n d h F, r b c L$, $t r n L-F$ and $t r n C-p s b M)$ were successfully amplified and directly sequenced for two individuals of Hyoscyamus labiatus. Seventy-five sequences from twenty-three species of seven genera of Hyoscyameae were obtained from the GenBank (Table S2). Sequence characteristics of these DNA fragments are presented in Table 2. Of the four cpDNA markers, $n d h \mathrm{~F}$ and $\operatorname{trnC}-p s b \mathrm{M}$ were characterized by high levels of length variation within the tribe Hyoscyameae (Table 2). The combined matrix of the four plastid markers from 25 samples comprises 5907 positions, of which 307 are variable (5.2\%) and 171 are parsimony-informative (2.9\%). 
Table 2

Statistics for the alignments of $n d h F, r b c L, \operatorname{trnC}-p s b M, \operatorname{trn} L-F$ and combined dataset

\begin{tabular}{|llllll|}
\hline & ndhF & rbcL & tm C-psbM & trnL-F & Combined \\
\hline No. & 25 & 23 & 22 & 21 & 25 \\
\hline Aligned length (bp) & 1990 & 1100 & 1920 & 896 & 5907 \\
\hline V & 112 & 20 & 99 & 69 & 307 \\
\hline PI & 60 & 12 & 70 & 29 & 171 \\
\hline $\begin{array}{l}\text { No., number of sequences (outgroups were not included). V, number of variable sites. Pl, number of } \\
\text { parismony-informative sites. }\end{array}$
\end{tabular}

Phylogenetic trees were firstly reconstructed based on four plastid markers with extensive taxon sampling. The phylogeny based on the combined four plastid loci supported the tribe Hyoscyameae as a monophyletic group and the monophyly of each genus was highly supported (Fig. 3). The new species was sister to all other Hyoscyamus, including Hyoscyamus leptocalyx (=Archihyoscyamus leptocalyx), with high support values (Fig. 3). For other genera within the tribe, Atropa was sister to the rest of the genera of the tribe, Przewalskia showed a close relationship with Anisodus (Fig. 3). But the relationships among the seven genera of the tribe Hyoscyameae were essentially unresolved due to low statistical support (Fig. 3). Phylogenetic trees based on individual plastid locus were not fully resolved due to the low phylogenetic signal of each molecular marker, especially for $r b c L$ (Fig. S1).

\section{Discussion}

Within the Hyoscyameae, the delimitation of Hyoscyamus has been hotly debated, mainly due to the controversial position of $H$. leptocalyx in different classifications. In 1972, Schöenbeck-Temesy transferred H. leptocalyx from sect. Chamaehyoscymus to sect. Pumilio within Hyoscyamus, due to its possession of flowers solitary, pedicel longer and calyx apex obtuse-rounded. In 1998, Khatamsaz described a new subgenus Parahyoscyamus, including H. leptocalyx and H. malekianus. In 1997, a monotypic genus Archihyoscyamus was described by Lu (1997) based on one species transferred from Hyoscyamus (H. leptocalyx). Archihyoscyamus was accepted by some later studies (Hunziker 2001; Zhang et al. 2005; Tu et al. 2010; Sanchez-Puerta and Abbona 2014; Ghahremaninejad and Riahi 2021). However, Archihyoscyamus leptocalyx (Stapf) A.M. Lu, is consistent to the other members in Hyoscyamus with the opercular dehiscence of the capsule due to a glandular enlargement on the summit of the ovarium (Miers 1850). Therefore, many taxonomists still considered A. leptocalyx as a member of Hyoscyamus (Sheidai et al. 2000; Hajrasouliha et al. 2014; Mabberley 2018).

With the rapid development of molecular systematics, the sister relationship between $H$. leptocalyx and all other previously described Hyoscyamus species was clearly revealed (Hajrasouliha et al. 2014; Ghahremaninejad and Riahi 2021). Our phylogenetic analysis also suggested that $H$. leptocalyx and other Hyoscyamus species formed a monophyletic clade with strong support $(\mathrm{BS}=96 \%)$ and H. labiatus is 
sister to this group with maximal support (BS=100\%) (Fig. 3). The treatment of $H$. labiatus in the genus is also supported by morphological characteristics. $H$. labiatus is most morphologically similar to $H$. leptocalyx by numerous, patent stems; solitary flowers on elongate pedicels in the leaf axils; spreading, subrotate fruiting calyx with reflexed lobes and without strong marginal veins, and incompletely enveloping the fruit. H. labiatus is also morphologically similar to other species in Hyoscyamus, such as $H$ senecionis Willd. and $H$. aureus $L$., by tall perennial herbs, 'labiate' flower with long tube, adaxial lips 3lobed and much longer than abaxial lips which are obviously different from $H$. leptocalyx, but differs in having lower corolla lip entire and fruit calyx with obtuse-rounded apex (Table 1).

\section{Conclusion}

Based on the above evidence, there is no doubt that the new species (described in the below), the controversial species (H. leptocalyx) and all other Hyoscyamus species have close relationships. But the affiliates among them did not mean $H$. labiatus and $H$. leptocalyx should be treated as separate monotypic genera, which inflates the taxonomy needlessly. Given their similarity in morphological characters (Table 1), we strongly suggested both H. labiatus and H. leptocalyx should be treated as members of Hyoscyamus, rather than separate monotypic genera. The new species described in this study, breaks down the difference between Archihyoscyamus and Hyoscyamus, so we propose to synonymize Archihyoscyamus with Hyoscyamus.

\section{Declarations}

\section{Acknowledgements}

We thank the curator of GXMI, IBK, IBSC, KUN, N, PE, SM, SN and WUK for the permission to use their scanned images of specimens and for research facilities. We are also grateful to Zhang Libing (Missouri Botanical Garden) for the revise of the manuscript, and Ms Liu Yao and Wang Fu-Qian for their kind help in the field collections.

\section{Author's contributions}

JML designed the research. YYL performed experiments. YYL, JML and ZLM analyzed the data. JML and QRW performed field investigations and collected the specimens. JML and YYL wrote the manuscript.

\section{Funding}

This study was supported by the National Natural Science Foundations of China (Grant Nos. 31270236, 32000170), Henan Province Major Research Fund of Public Welfare (201300110900), Foundation of He'nan Educational Committee (19B180004) and the project named "investigation on forest genetic resources" (No. 30801731) from Henan Economic Forest and Forest seedling Workstation.

\section{Availability of data and materials}


All DNA sequences generated in this study have been registered to GenBank.

\section{Ethics approval and consent to participate}

Not applicable.

\section{Consent for publication}

Not applicable.

\section{Competing interests}

The authors declare that they have no competing interests.

\section{References}

D'Arcy WG, Zhang Z-Y (1992) Notes on the Solanaceae of China and neighboring areas. Novon 2: 124128.

Dong W, Cheng T, Li C, Xu C, Zhou S (2014) Discriminating plants using the DNA barcode $r b c L b$ : an appraisal based on a large data set. Mol Ecol Resour 14: 336-343. http://doi.org/10.1111/17550998.12185

Ghahremaninejad F, Riahi M (2021) The systematic position of Archihyoscyamus A.M.Lu (Solanaceae Juss.): an analysis based on nuclear and plastid sequences. Bot Lett 168: 96101. http://doi.org/10.1080/23818107.2020.1824806

Hajrasouliha S, Maassoumi AA, Sattar TN, Mohammad S, Hamdi M, Mehregan I (2014) A phylogenetic analysis of Hyoscyamus L. (Solanaceae) species from Iran based on ITS and trnL-F sequence data. J Bio Env Sci 5: 647-654.

Hall TA (1999) BioEdit: a user-friendly biological sequence alignment editor and analysis program for Windows 95/98/NT. Nucl Acids Sym Ser 41: 95-98. http://doi.org/10.1021/bk-1999-0734.ch008 Hunziker AT (2001) The Genera of Solanaceae. ARG Gantner, Ruggell.

Knapp S (2002) Tobacco to tomatoes: a phylogenetic perspective on fruit diversity in the Solanaceae. J Exp Bot 53: 2001-2022. http://doi.org/10.1093/jxb/erf068

Lei F-W, Tong L, Zhu Y-X, Mu X-Y., Tu T-Y, Wen J (2021) Plastid phylogenomics and biogeography of the medicinal plant lineage Hyoscyameae (Solanaceae). Plant Diversity 43: 192-197. https://doi.org/10.1016/j.pld.2021.01.005

Lu A-M (1997) Archihyoscyamus: a new genus of Solanaceae from western Asia. Adansonia 19: 135138. 
Lu A-M, Zhang Z-Y (1986) Studies of the subtribe Hyoscyaminae in China. In: D'arcy WG (ed) Solanaceae: Biology and Systematics. Columbia University Press, New York, pp. 56-78.

Miers J (1850) On Scopolia, Anisodus and Mandragora. Ann Mag Nat Hist 6: 35-41.

Olmstead R, Sweere J (1994) Combining data in phylogenetic systematics: an empirical approach using three molecular data sets in the Solanaceae. Syst Biol 43: 467481. http://doi.org/10.1093/sysbio/43.4.467

Olmstead RG, Sweere JA, Spangler RE, Bohs J, Palmer JD (1999) Phylogeny and provisional classification of the Solanaceae based on chloroplast DNA. In: Nee M, Symon D, Lester RN, Jessop J (eds) Solanaceae IV: Advances in Biology and Utilization. Royal Botanic Gardens, Kew, pp. 111-137.

Olmstead RG, Bohs L, Migid HA, Santiago-Valentin E, Garcia VF, Collier SM (2008) A molecular phylogeny of the Solanaceae. Taxon 57: 1159-1181. http://doi.org/10.1002/tax.574010

Stamatakis A (2014) RAxML Version 8: a tool for phylogenetic analysis and post-analysis of large phylogenies. Bioinformatics 30: 1312-1313. http://doi.org/10.1093/bioinformatics/btu033

Sanchez-Puerta MV, Abbona CC (2014) The chloroplast genome of Hyoscyamus niger and a phylogenetic study of the tribe Hyoscyameae (Solanaceae). PLoS ONE 9:

e98353. http://doi.org/10.1371/journal.pone.0098353

Satil F Aslan M, Erdoğan E, Polat R, Selvi S (2015) Comparative anatomical studies on some species of Hyoscyamus L.(Solanaceae) growing in Turkey. Bangladesh J Bot 44: 37-

43. http://doi.org/10.3329/bjb.v44i1.22721

Schöenbeck-Temesy E (1972) Solanaceae. In: Rechinger K H (ed) Flora Iranica 100: Akademische Druck und Verlagsanstalt, Graz, pp, 49-79.

Sheidai M, Mosallanejad M, Khatamsaz M (1999) Karyological studies in Hyoscyamus species of Iran. Nord J Bot 19: 369-374. http://doi.org/10.1111/j.1756-1051.1999.tb01130.x

Sheidai M, Mosalanezhad M, Khatamsaz M (2000) Numerical taxonomy and seed protein analysis of Hyoscyamus species in Iran. J Sci I R Iran 11: 83-91.

Taberlet P, Gielly L, Pautou G, Bouvet J (1991) Universal primers for amplification of three noncoding regions of chloroplast DNA. Plant Mol Biol 17: 1105-1109. http://doi.org/10.1007/BF00037152

Thompson JD, Gibson TJ, Plewniak F, Jeanmougin F, Higgins DG (1997) The CLUSTAL_X windows interface: flexible strategies for multiple sequence alignment aided by quality analysis tools. Nucl Acids Res 25: 4876-4882. http://doi.org/10.1093/nar/25.24.4876 
Tu T-Y, Dillon MO, Sun H, Wen J (2008) Phylogeny of Nolana (Solanaceae) of the Atacama and Peruvian deserts inferred from sequences of four plastid markers and the nuclear $L E A F Y$ second intron. Mol Phylogenet Evol 49: 561-573. http://doi.org/10.1016/j.ympev.2008.07.018

Tu T-Y, Volis S, Dillon M, Sun H, Wen J (2010) Dispersals of Hyoscyameae and Mandragoreae (Solanaceae) from the New World to Eurasia in the early Miocene and their biogeographic diversification within Eurasia. Mol Phylogenet Evol 57: 1226-1237. http://doi.org/10.1016/j.ympev.2010.09.007

Yousaf Z, Masood S, Shinwari ZK, Khan AM, Rabani A (2008) Evaluation of taxonomic status of medicinal species of the genus Hyoscyamus, Withania, Atropa and Datura based on polyacrylamide gelelectrophoresis. Pak J Bot 40: 2289-2297.

Yuan Y, Zhang Z-Y, Chen Z-D, Olmstead RG (2006) Tracking ancient polyploids: a retroposon insertion reveals an extinct diploid ancestor in the polyploid origin of belladonna. Mol Biol Evol 23: 22632267. http://doi.org/10.1093/molbev/msl099

Zhang Z-Y, Lu A-M, D'Arcy WG (1994) Solanaceae. In: Wu Z-Y, Raven PR (eds) Flora of China vol 17, Science Press and Missouri Botanical Garden Press, Beijing and St. Louis, pp 300-332.

Zhang Z-Y, Yang D-Z, Lu A-M, Knapp S (2005) Seed morphology of the tribe Hyoscyameae (Solanaceae). Taxon 54: 71-83. http://www.jstor.org/stable/25065303

\section{Figures}




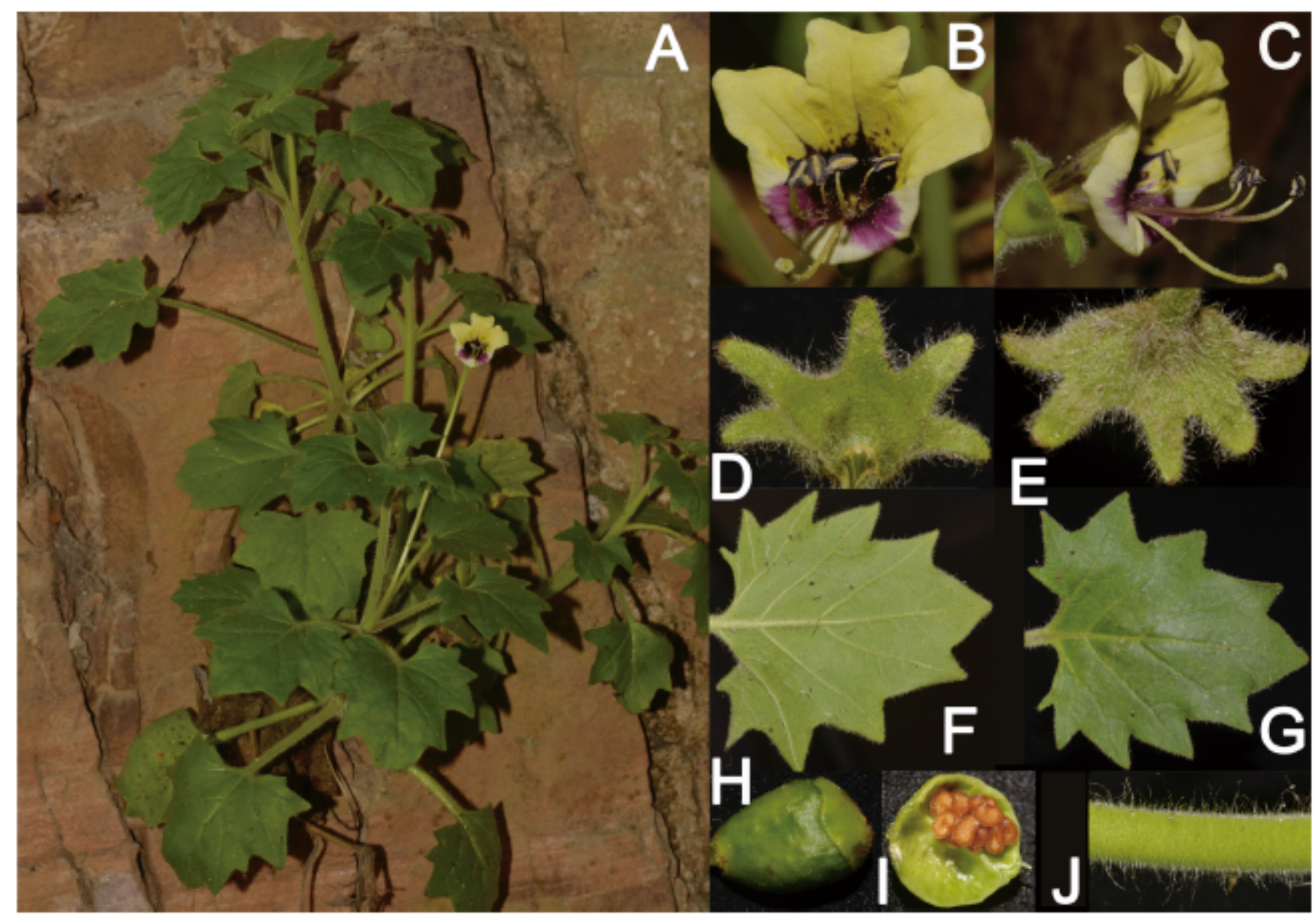

Figure 1

Hyoscyamus labiatus Y.Y. Liu, Q.R. Wang and J.M. Li sp. nov. A habitat B Frontal view of a flower C Lateral view of a flower $D$ Inside of calyx $E$ Outside of calyx $F$ Abaxial leaf surfaces $G$ Adaxial leaf surfaces H Fruit I Open fruit showing seeds J Stem. All photos by J.M. Li. (colored) 


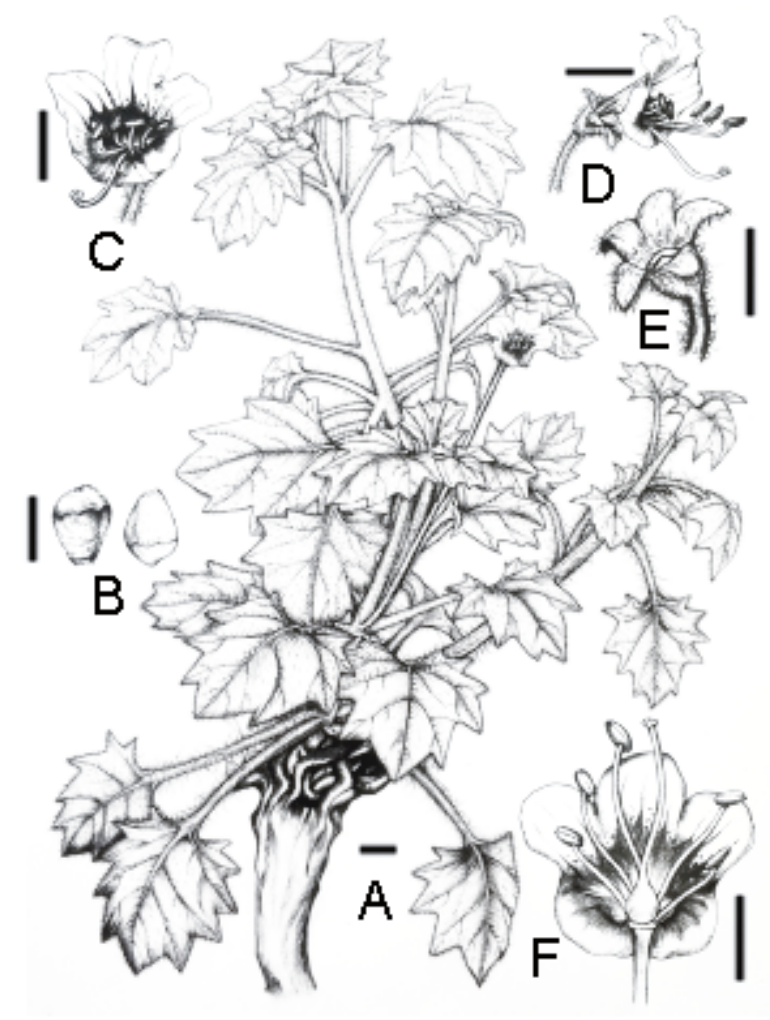

Figure 2

Hyoscyamus labiatus Y.Y. Liu, Q.R. Wang and J.M. Li sp. nov. A Habit B Up and down view of fruits C Frontal view of a flower $D$ Lateral view of a flower $E$ Calyx $F$ Open flower. scale bar $=1 \mathrm{~cm}$. Drawn by $\mathrm{Mi}$ ZengLou from Li Jiamei and Wang Qirui 20205221. 


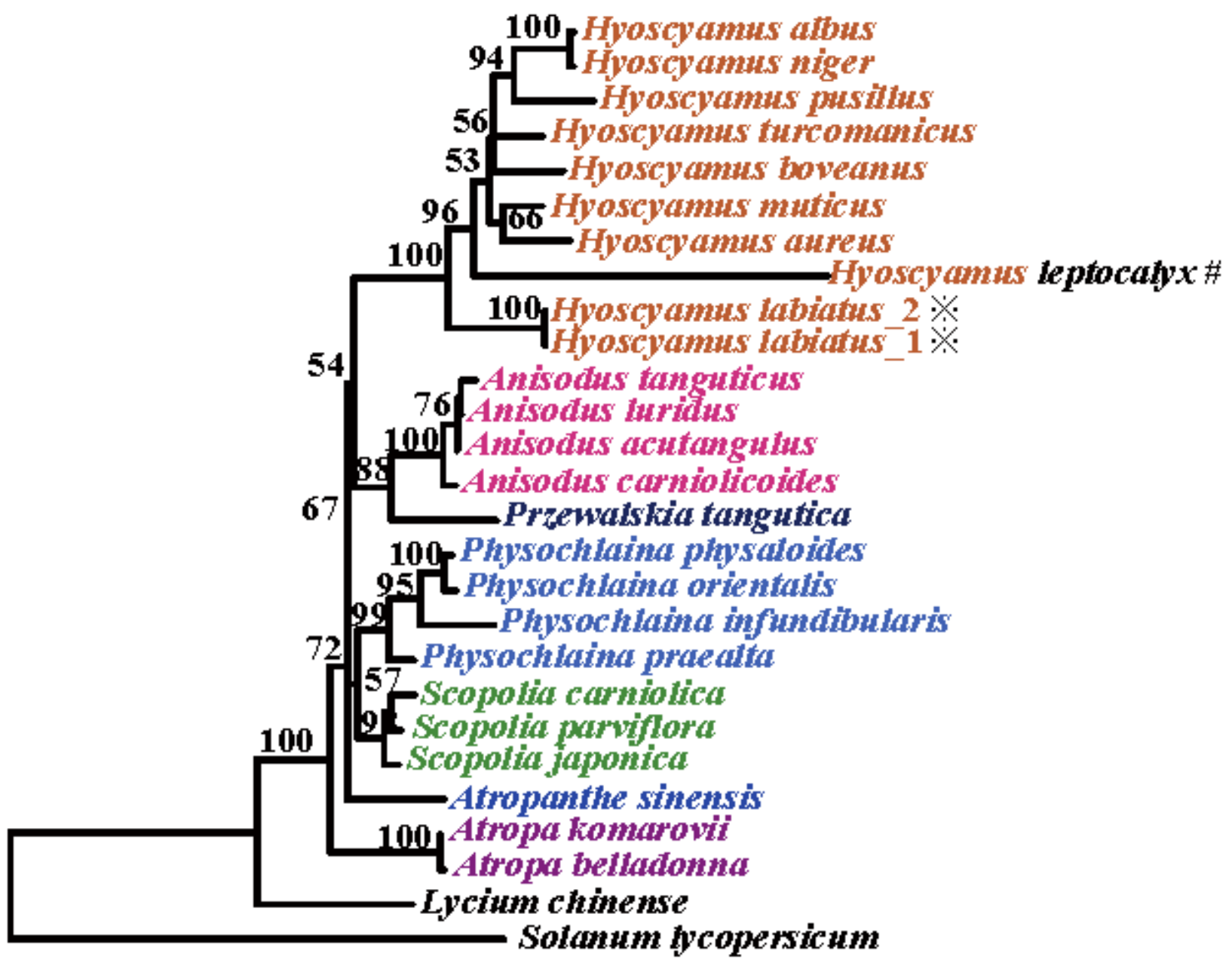

0.004

Figure 3

Maximum likelihood tree constructed with the combined four plastid genes. The numbers on the branches indicate bootstrap values $>50 \%$. \# Treated as Archihyoscyamus leptocalyx by Lu (1997). ※The new species described in our study. (colored)

\section{Supplementary Files}

This is a list of supplementary files associated with this preprint. Click to download. 
- Supplementarydata.docx

Page 15/15 